\title{
INTERCULTURAL COMMUNICATIVE COMPETENCE IN ELT: LECTURERS' PERCEPTION AND PRACTICE
}

Umi Fitriyah, alrosyadafitry@gmail.com, state university of surabaya, Indonesia Pratiwi Retnaningdyah,pratiwi@unesa.ac.id, state university of surabaya, Indonesia Ahmad Munir, ahmadmunir@unesa.ac.id, state university of surabaya, Indonesia

\begin{abstract}
English has already been a global lingua franca which is commonly used to communicate in many different purposes and situations, such as global trade, global education, intercultural connection, business, and so forth. It is inevitable that this phenomenon initiates the emergence of intercultural communication. Therefore, today's English Language Teaching (ELT) should emphasize the importance of intercultural communication competence (ICC). This study aims to gain an in-depth understanding of this issue by investigating English lecturers' perception and practice on ICC in ELT. Questionnaire and interview were employed to explore the lecturers' perception of ICC in ELT, while for the practice, observation was used. The findings indicate positive attitudes of English lecturers of ICC in ELT; however, less exploration of ICC during grammatical related subject has become a certain challenge for the lecturer. Overall, some possible measures to enhance ICC engagement in ELT in this context are proposed.

Keywords: Intercultural Communicative Competence (ICC), English Language Teaching(ELT), Lecturers' Perception and Practice.
\end{abstract}

\section{Introduction}

Due to globalization rapid increase, the need to cooperate with people from different cultures is inevitable. EFL classes are recognized as a potent condition for promoting intercultural communicative competence (ICC) (Alptekin, 2002; Byram, 1994; Vo, 2016). Byram (1997, p.7) states "the days of teaching only native speakers' cultures and ignoring the significance of the social identities and cultural competence of the learner in any intercultural interaction are over". Similarly, according to Council of Europe (2001), "English language teaching and learning should not be solely purposed for acquiring communicative competence in a foreign language which refers to a person's ability to act in a foreign language linguistically, socio-linguistically and pragmatically". To some extent, it is aimed at the intercultural competence which is "the ability of a person to behave adequately in a flexible manner when confronted with actions, attitudes and expectations of representatives of foreign cultures" (Meyer, 1991, p. 138). ICC will initiate the individual and social development of the learner since it helps students to develop cultural knowledge and the ability to understand the target culture as well as their own. 
Despite its conceptual importance in today's context, there is still a little concern on ICC studies especially in Indonesian context. However, some research have revealed teachers' positive perceptions of ICC in ELT (Gandana, 2014; Osman, 2015; Yildiz, 2016; Vo, 2017), but highlighted the challenges that were confronted by many teachers in the implementation (Vo, 2017). Therefore, this present study was born to explore deeper understanding of teachers' perceptions and practices in integrating intercultural communication competence in ELT especially within Indonesian tertiary education. The research questions were addressed to investigate the lecturers' perception of ICC in ELT classroom, how they apply ICC in EFL classroom activities, and the gap between their perception and their practice.

Intercultural communicative competence includes two sub competencies. First, communicative competence which includes linguistic competence, sociolinguistic competence, and discourse competence; second, intercultural competence can be specifically explained as intercultural attitudes which is explained as curiosity, openness, or readiness to suspend disbelief about other cultures and belief about one's own; intercultural knowledge which shows learning about social groups, products, practices, and processes of interaction; skills of interpreting and relating which are understood as the abilities to identify and explain cultural perspectives and mediate between and function in new cultural contexts; discovery and interaction which is purposed to develop ethnographic and research skills and exploring cultures; and education is meant as evaluating political education and developing critical cultural awareness (Byram, 1997).

The perception of ICC represents the cognitive process and structures that inspire, and are inspired by, what teachers do. This unobservable cognitive dimension of thinking includes beliefs, knowledge, principles, theories, and attitudes, in addition to the thoughts and reflections teachers have before, during and after teaching (Borg, 2003).

Guilherme's (2002) study on Portuguese teachers revealed that ICC activities they employed focused on comparative and/or contrastive activities. Describing the values the participants hold, norms the participants follow, and their overall perception of intercultural communicative competence are also important to determine how teachers perceive intercultural aspect of language teaching. $f$ 
In 1990s, particularly Europe, USA and Australia witnessed a substantial intensification of encounters between different national cultures in the education field. This had been brought about by, among other things, an explosion within the field of Information and Communication Technology (ICT) and an internationalization of education through various study abroad programs (Risager, 2007). It was during this period that the discourse of 'intercultural' first gained its significance.

Perry and Southwell (2011) note that, as a pedagogy, education for intercultural understanding is often embedded in academic subjects such as foreign languages and social studies. They observe that the potential for the incorporation of such intercultural pedagogy into the curriculum is increasing in some countries, including in Australia. Indonesia has also started to do the same (Gandana, 2014). Narrowing down the context to foreign language education, the intercultural approach is considered to be the most recent approach to language teaching and learning. While intersecting with ELT, as the context of the study is English Departments in Indonesian universities, interculturalism here is examined in terms of broader, inclusive notions of pedagogy (Giroux, 1988, 1991, 1997) rather than as a single approach to teaching English.

In EFL classroom, when teachers teach language, they also automatically teach culture. Teachers at least introduce some references about culture through language. Gesture, body movement, and distance maintained by speakers should foster cultural insight (Cakir, 2006). If language learners are to communicate at a personal level with individuals from other cultural backgrounds, they need not only to understand the cultural influences at work in the behavior of others, but also to recognize the reflective influence patterns of their own culture exert over their thoughts, their activities, and their forms of linguistics expression (Cakir, 2006). It donates that teachers can instruct their students to be curious about the way foreign speakers perform culture in language.

In order to seek and answer to the question of how frequently these culture teaching practices are handled in EFL classrooms, Atay et al. (2009) analyzed data gathered from 503 Turkish EFL teachers who were provided with a questionnaire including questions on culture teaching practices as well as how frequently they incorporate culture teaching. Teachers claimed that they sometimes incorporate culture teaching practices. 


\section{RESEARCH METHOD}

The convergent parallel design of mixed method was employed in this study. The purpose of convergent parallel design is to illustrate quantitative findings to describe how is the gap between the lecturer's perception and their practice. Creswell (2014) states that the quantitative and qualitative data are analyzed separately but finally related to confirm or disconfirm each other. It can be seen in the following figure:

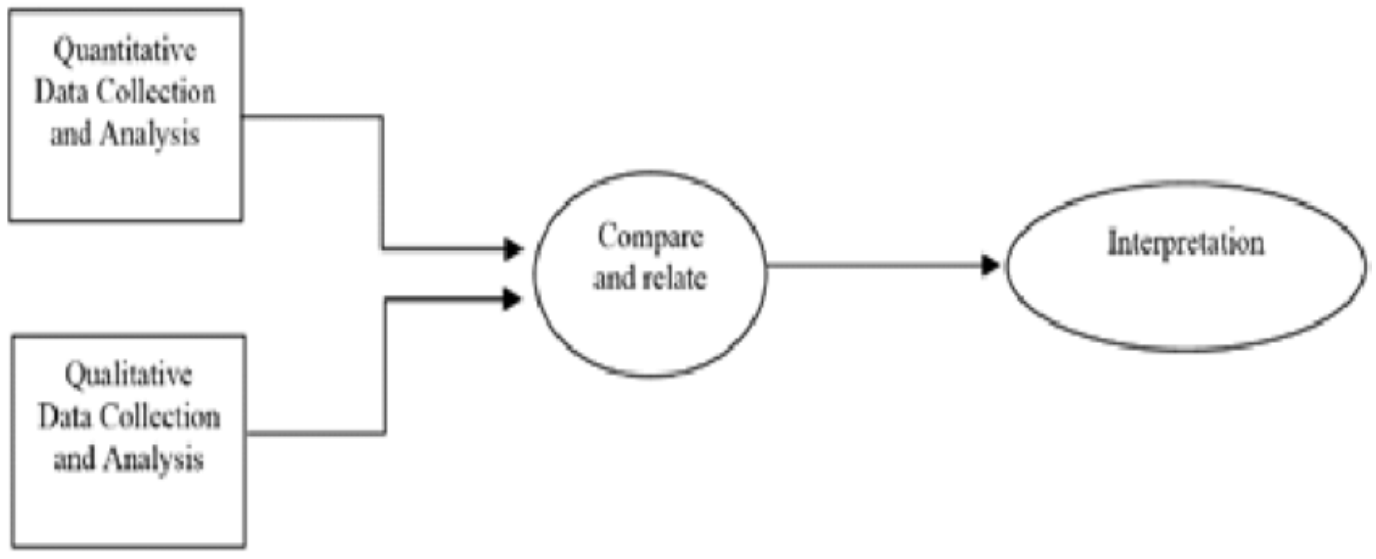

Figure 1. Adapted from Creswell (2014,p.220)

The subjects were three out of twenty lecturers from three universities who were chosen randomly based on the questionnaire about perceptions of ICC given previously. One of the universities is a private university in Gresik which is called UNMUH Gresik, the others are a private university in Surabaya which is called UNUSA and State Islamic University Sunan Ampel.

The first technique in collecting data of the lecturer's perception of ICC was questionnaire. It was distributed to 20 lecturers of three universities in order to get their perceptions of ICC in English language teaching. The items of questionnaire were adapted from Sercu (2005) using Likert scale.

The interview was used to support data gotten from questionnaire. It was done for three out of twenty participants selected using random sampling. The form was semistructured individual interviews. The main advantage of these interviews is to create the opportunity to gain access to what is explained as "inside a person's head" (Cohen \& Manion, 1994, p.272).

Assessment tools like essays, midterms and finals, projects, and portfolios, as well as program-specific questionnaires, self-assessments, and interviews are the tools most commonly used for assessing ICC outcomes in college-level foreign language 
programs in the United States (Sinicrope, Norris \& Watanabe, 2007). These tools can be used to collect both direct evidence (e.g., learning contract, e-portfolio, and critical reflection) and indirect evidence (e.g., surveys, inventories). It is important to use a combination of direct and indirect measures to ensure that the results are obtained from subjective, personalized tools as well as from objective, generic tools."

In this study, non-participant observation was employed because the researcher did not involve in the learning activities, instead, he observed how the lecturers implement ICC in English classroom activities. Creswell (2012) states that non-participant observation is useful to notice unusual aspects during observation. In order to select the participants to be observed in the classroom, the reseacher chose the lecturer who had the lowest score, the medium score and the highest score respectively. To keep the confidentiality of this research, every participant was given a pseudonym. L1 was the participant who got the lowest mean, L2 with the medium mean, L3 with the highest score.

Data about the lecturers' perception toward intercultural communicative competence in ELT gotten from questionnaires were analyzed through descriptive quantitative method. It used frequency test with SPSS 20.0 to know the average mean of the lecturers' perception toward ICC in ELT. In addition, transcripts from interviews were analyzed based on the similarity answering the perception points.

The data of the lecturers' implementation of ICC gained from non-participant observation were analyzed qualitatively using multidimensional model for the development intercultural literacy by Heyward (2002). This model integrates the key features reiterated in many into a more explicitly articulated multidimensional model. In characterizing the desired end point as intercultural literacy, he highlights the focus on learning. The model assumes that culture is constructed, it defines groups within and between societies, it is fluid and changing, and it is learned. The lecturers who were being observed were characterized into five levels of this model. They are monocultural level 1 named limited awareness which is identified as unconsciously incompetence; monocultural level 2 called naïve awareness which is identified as unconsciously incompetence; monocultural level 3 that is engagement-distancing identified as consciously incompetence; cross cultural level emerging intercultural literacy which is identified as consciously competence; and intercultural level named bicultural or transcultural which is identified as unconsciously competence. 


\section{RESEARCH FINDINGS}

\subsection{Lecturers' perception of Intercultural Communicative Competence in English}

\section{Language Teaching}

It is found that most of the lecturers have positive perception of ICC in ELT. It is illustrated in the following table.

Table 1. The average lecturer's perception of ICC in ELT

\begin{tabular}{|c|c|c|c|}
\hline No & ITEMS & $\bar{X}$ & SD \\
\hline 1. & $\begin{array}{l}\text { In a foreign language classroom, teaching culture is as important as teaching } \\
\text { the foreign language. }\end{array}$ & 4.45 & .51 \\
\hline 2 . & Intercultural education has no effect whatsoever on students' attitudes & 1.50 & .51 \\
\hline 3. & $\begin{array}{l}\text { In intemational contacts misunderstandings arise equally often from linguistic } \\
\text { as from cultural differences. }\end{array}$ & 3.95 & 1.09 \\
\hline 4. & $\begin{array}{l}\text { All students should acquire intercultural } \\
\text { competence, not only pupils in classrooms with ethnic minority commurities. }\end{array}$ & 4.45 & .51 \\
\hline 5. & $\begin{array}{l}\text { A foreign language teacher should present a } \\
\text { realistic image of a foreign culture (e.g., touching upon positive \& negative } \\
\text { sides of the foreign culture and society). }\end{array}$ & 4.55 & .51 \\
\hline 6. & $\begin{array}{l}\text { Language and culture carmot be taught in an } \\
\text { integrated way. }\end{array}$ & 1.35 & .48 \\
\hline 7. & $\begin{array}{l}\text { I would like to teach intercultural competence } \\
\text { through my foreign language teaching. }\end{array}$ & 4.10 & .71 \\
\hline 8. & $\begin{array}{l}\text { Providing additional cultural information makes pupils more tolerant towards } \\
\text { other cultures and people. }\end{array}$ & 4.45 & .51 \\
\hline 9. & $\begin{array}{l}\text { Foreign language teaching should not only touch up on foreign cultures. It } \\
\text { should also deepen pupils' understanding of their own culture. }\end{array}$ & 4.55 & .51 \\
\hline 10. & $\begin{array}{l}\text { It is not the language teacher's task to teach about the foreign culture and } \\
\text { country. }\end{array}$ & 1.50 & .68 \\
\hline 11. & $\begin{array}{l}\text { It is the task of the teacher to present a positive } \\
\text { image of the foreign culture and society. }\end{array}$ & 3.65 & .48 \\
\hline 12. & $\begin{array}{l}\text { The cultural dimension in language teaching is } \\
\text { more important than the linguistic dimension. }\end{array}$ & 2.80 & .95 \\
\hline 13. & $\begin{array}{l}\text { If there is a lot of time pressure, culture teaching should give way to linguistic } \\
\text { teaching. }\end{array}$ & 3.60 & .50 \\
\hline 14. & $\begin{array}{l}\text { I consider the introduction of "cultural awareness" into the national } \\
\text { curriculum as an important innovation. }\end{array}$ & 4.25 & .44 \\
\hline 15. & $\begin{array}{l}\text { All English-speaking cultures around the world are equally valid to be } \\
\text { represented in an English svllabus. }\end{array}$ & 3.55 & .68 \\
\hline 16. & $\begin{array}{l}\text { Leaming about a foreign culture can change the student's attitude towards } \\
\text { his/her own culture. }\end{array}$ & 4.05 & .68 \\
\hline
\end{tabular}

Table 1 illustrates that most of the lecturers have a positive perception of ICC. Accordingly, they reported that language and culture should be taught in an integrated way and culture is as important as teaching the language (see item 1). They mostly do not believe that cultural aspect of language teaching is more important than the linguistic aspect of language teaching (see item 12). Participants also reported that they view themselves as the cultural mediator to teach culture in classroom by presenting a realistic image of a foreign culture, and they believed incorporating cultural awareness into the national curricula to be an important innovation which can help students develop a tolerance towards other cultures. Almost half of the participants chose 'agree to a certain extent' when 
they were asked if there is time pressure, culture teaching should give way to linguistic teaching. Another interesting finding is that, nearly half of the participants reported that they did not receive help from their teacher-training courses regarding how to teach the cultural dimension of language. This might mean that culture teaching has not been fully incorporated into the teacher training curriculums. It can be concluded that in spite of the fact that tertiary level Turkish EFL teachers have positive perception on ICC regarding culture teaching objectives, culture teaching activities and intercultural foreign language teaching, the amount of time allocated for culture teaching in the reported classroom application is low.

Moreover, results from interviews indicated that all lecturers are aware of the importance of ICC in ELT. Their responses were related to the the questionnaire that they had filled. Therefore, when they were asked about teaching in a foreign language classroom, they perceived that teaching culture is as important as teaching the foreign language and both language and culture can be taught in an integrated way. Overall, the interviews revealed that most lecturers show their high agreement on how ICC can be developed in ELT.

In general, nearly all of the lecturers are aware of the importance of ICC in ELT. Their views are further explained regarding its strong mutual support to effective language communicative competence, deeper understanding of various aspects of worldwide countries, and limiting cultural aspects' misunderstanding.

\subsection{Lecturers' Implementation of Intercultural Communicative Competence in English Language Teaching}

Table 2 below shows ICC criteria which L1 employed in the observation. In the observation, L1 was teaching grammar class during which the lecturer was concerned with the review of previous lesson and the stucture of a sentence. The understanding, competencies, attitude, participants and identities categories are in the Monocultural Level 3 engangement-Distancing (conciously incompetence). 


\begin{tabular}{|c|c|c|c|c|c|c|}
\hline No. & Indicators & $\begin{array}{c}\text { Monocultural } \\
\text { Level 1 } \\
\text { Limited } \\
\text { Awareness } \\
\text { (Unconciously } \\
\text { Incompetence) }\end{array}$ & $\begin{array}{c}\text { Monocultural } \\
\text { Level 2 } \\
\text { Naive } \\
\text { Awareness } \\
\text { (Unconciously } \\
\text { Incompettenoe) }\end{array}$ & $\begin{array}{c}\text { Monocultural } \\
\text { Level } 3 \\
\text { Engagement- } \\
\text { Distancing } \\
\text { (Conciously } \\
\text { Incompetence) }\end{array}$ & $\begin{array}{c}\text { Crosscultural } \\
\text { Level } \\
\text { Emerging } \\
\text { Intercultural } \\
\text { Literacy } \\
\text { (Conciously } \\
\text { Competence) }\end{array}$ & $\begin{array}{l}\text { Intercultural } \\
\text { Level } \\
\text { Bicultural or } \\
\text { Transcultural } \\
\text { (Unconcioushy } \\
\text { Competence) }\end{array}$ \\
\hline 1. & Understanding & & & 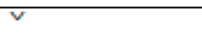 & & \\
\hline 2. & Competencies & & & v & & \\
\hline 3. & Attitudes & & & v & & \\
\hline 4. & Participation & & & & & \\
\hline 5. & $\begin{array}{l}\text { Language } \\
\text { Proficiencies }\end{array}$ & & & - 울 $(\mathrm{Ctrl})=$ & & \\
\hline 6. & Identities & & & v & & \\
\hline
\end{tabular}

Table 2. The Result of L1's Observation

From the table 2, ICC context does not appear during the class. Even though the lecturer taught grammar, he did not give any examples of sentences which were related to ICC. For the language proficiency, the L1 is in crosscultural level emerging Intercultural literacy (conciously competence), the L1 has good ability to speak in second laguage and practice in the class.

The following table 3 shows ICC perception criteria which L2 employed in the observation. In the observation, L2 taught listening practice for the proficiency exam. She was mainly concerned with playing pre-recorded listening tasks on a tape recorder and students followed the recordings and fulfilled the tasks.

\begin{tabular}{|l|l|l|l|l|l|l|}
\hline No. & \multicolumn{1}{|c|}{ Indicators } & $\begin{array}{c}\text { Monocultural } \\
\text { Level 1 } \\
\text { Limited } \\
\text { Awareness } \\
\text { (Unconciousty } \\
\text { Incompetence) }\end{array}$ & $\begin{array}{c}\text { Monocultural } \\
\text { Level 2 } \\
\text { Naive } \\
\text { Awareness } \\
\text { (Unconciousb } \\
\text { Incompetence) }\end{array}$ & $\begin{array}{c}\text { Monocultural } \\
\text { Level 3 } \\
\text { Engagement- } \\
\text { Distancing } \\
\text { (Conciously } \\
\text { Incompetence) }\end{array}$ & $\begin{array}{c}\text { Crosscultural } \\
\text { Level } \\
\text { Emerging } \\
\text { Intercultural } \\
\text { Literacy } \\
\text { (Conciously } \\
\text { Competence) }\end{array}$ & $\begin{array}{c}\text { Intercultural } \\
\text { Level } \\
\text { Bicultural or } \\
\text { Transcultural } \\
\text { (Unconciously } \\
\text { Competence) }\end{array}$ \\
\hline 1. & Understanding & & & & $V$ & \\
\hline 2. & Competencies & & & $V$ & & \\
\hline 3. & Attitudes & & & & $V$ & \\
\hline 4. & Participation & & & & & \\
\hline 5. & $\begin{array}{l}\text { Language } \\
\text { Proficiencies }\end{array}$ & & & & $V$ & \\
\hline 6. & Identities & & & & & \\
\hline
\end{tabular}

Table 3. The Result of L2's Observation

The table shows that the L2's competence category is in the Monocultural Level 3 engangement-Distancing (conciously incompetence). The L2 seems to develop competence 
include mindfulness, emphathy, perspective- taking, tolerance, and communication during the class. The understanding, attitude, participation, and identities categories are in crosscultural level emerging Intercultural literacy (conciously competence). The L2 gave a lot of ICC examples during listening class. She played the cassete of listening from oxford books and found so much cross cultural understanding in the cassete that she played. Even though not all of the parts in listening section were explained, it was clear enough from some parts that she had explained.

Table 4 below illustrates the participant who got the highest mean of the questionnaire.

\begin{tabular}{|c|c|c|c|c|c|c|}
\hline No. & Indicators & $\begin{array}{l}\text { Monocultural } \\
\text { Level l } \\
\text { Limited } \\
\text { Awareness } \\
\text { (Unconciously } \\
\text { Incompetence) }\end{array}$ & $\begin{array}{l}\text { Monocultural } \\
\text { Level 2 } \\
\text { Naive } \\
\text { Awareness } \\
\text { (Unconciously } \\
\text { Incompetence) }\end{array}$ & $\begin{array}{l}\text { Monocultural } \\
\text { Level } 3 \\
\text { Engagement- } \\
\text { Distancing } \\
\text { (Conciously } \\
\text { Incompetence) }\end{array}$ & $\begin{array}{c}\text { Crosscultural } \\
\text { Level } \\
\text { Emerging } \\
\text { Intercultural } \\
\text { Literacy } \\
\text { (Conciously } \\
\text { Competence) }\end{array}$ & $\begin{array}{l}\text { Intercultural } \\
\text { Level } \\
\text { Bicultural or } \\
\text { Transcultural } \\
\text { (Unconciousb } \\
\text { Competence) }\end{array}$ \\
\hline 1. & Understanding & & & & $\mathrm{v}$ & \\
\hline 2. & Competencies & & & & & $\mathrm{v}$ \\
\hline 3. & Attitudes & & & & & $\mathrm{v}$ \\
\hline 4. & Participation & & & & & $\mathrm{v}$ \\
\hline 5. & $\begin{array}{l}\text { Language } \\
\text { Proficiencies }\end{array}$ & & & & & $\mathrm{v}$ \\
\hline 6. & Identities & & & & $\mathrm{v}$ & \\
\hline
\end{tabular}

Table 4. The Result of L3's Obsevation

Table 4 shows ICC perception criteria which L3 employed in the observation. In the observation, L3 focused on speaking practice. He was mainly concerned with inviting the students to deliver the opinion about the topic that he had given. The topic was about "Beauty Contest", so there were a lot of ICC contexts that the researcher found during the class.

The understanding and identities categories are in the crosscultural level emerging intercultural literacy (conciously competence) and the competencies, attitudes, participation and language proficiencies categories are in the intercultural level bicultural or transcultural (unconciously competence). The L3 did not only invite the students to give opinions related to the topic but also asked the students to mention the ICC contecxt that found in "beauty contest" all over the world.

\section{CONCLUSION AND RECOMMENDATION}


The current survey with the English lecturers shows that they are well aware of intercultural communication competence in English language teaching. For the practice, it can be concluded that it is a little bit difficult for the lecturer to practice the ICC in grammar class, whereas in listening and speaking class it is easier. The lecturer could determine which topic is suitable for delivering ICC in the class. Even though almost all the lecturers in this study had positive responses on ICC in English language teaching, only the lecturers who taught listening and speaking lesson could deliver ICC in ELT Class. Certain challenges confronted by their implementations have been highlighted. As a result, some possible measurements to enhance ICC engagement in ELT in this context are proposed. Further research in the current context need to be expanded for the observation; future researcher needs to observe more classes with different subjects.

\section{REFERENCES}

Alptekin, C. (2002). Towards intercultural communicative competence in ELT. ELT Journal Volume 56, 57-64.

Atay, D. (2005). Reflections on the cultural dimension of language teaching. Language and Intercultural Communication, 222-236.

Bastos, M. (2015). Pathways to teacher education for intercultural communicative competence: teachers' perceptions. The Language Learning Journal, 43(2), 131-147.

Byram, M. (. (1997). T eaching and Assessing Intercultural Communicative Competence. Bristol, England: Multilingual Matters.

Byram, M. a. (1999). Language Teachers, Politics, and Cultures. Clevedon,. England: Multilingual Matters.

Castle sinicrope, J. N. (2007). Understanding and assessing intercultural competence : A summary of theory,research, and practice. . Second Language Study, 1-58.

Clouet, R. (2012). Studying the role of intercultural competence in language teaching in upper secondary education in the Canary Islands. Onomázein, 309-334.

council, E. (2001). Common European Framework of Reference for langue learning, teaching, assessment. Cambridge: Cambridge University Press.

Creswell, J. W. (2009). Research design: Qualitative, quantitative, and mixed methods. Thousand Oaks: SAGE Publications.

Eken, D. (2015). Intercultural communicative competence: EFL teachers' beliefs and practices. Journal of Teaching and Education, 63-71.

Eken, D. T. (2015). Intercultural communicative competence: EFL teachers' beliefs and practices". . Journal of T eaching and Education, 63-71.

Fantini, A. E. (2009). Assessing intercultural competence: Issues and tools. In D. Deardorff (Ed.). In A. E. Fantini, The SAGE handbook of intercultural competence (pp. 456476). Thousand Oaks: SAGE Publications.

Firth, A. (1996). The discursive accomplishment of normality: On 'lingua franca' English and conversation analysis. . Journal of Pragmatics, 26, 237-259.

Gandana, I. (2013). Professional identity, curriculum and teaching Intercultural Communication:an Indonesian case study. Language, Culture and Curriculum, 230246.

Hymes, D. (1972). Models of the interaction of language and social life. Directions in sociolinguistics, 35-71. 
Osman, H. A. (2015). Investigating English $T$ eachers' $P$ erceptions of Intercultural Communicative Competence in the Kingdom of Saudi Arabia. San Fransisco: University of San Francisco.

Sercu, L. (2005). Foreign language teachers and the implementation of intercultural education: a comparative investigation of the professional self-concepts and teaching practices of Belgian teachers of English, French and German. European Journal of Teacher Education, 87-105.

Sercu, L. (2006). The foreign language and intercultural competence teacher: the acquisition of a new professional identity. Intercultural Education, 55-72.

VO, Q. P. (2017). Rethinking Intercultural Communication Competence . i-manager's Journal on English Language Teaching , 20-29.

YILDIZ, İ. M. (2016). Tertiary Level EFL Teachers' Perceptions And Practices of ICC (Published master thesis). Turkey: İHSAN DOĞRAMACI BILLKENT UNIVERSITY. 